\title{
STRATEGI BADAN PENGAWAS PEMILU DALAM PENGAWASAN KETERLIBATAN APARATUR SIPIL NEGARA (ASN) PADA PEMILIHAN UMUM DI PROVINSI JAWA BARAT
}

\author{
Oleh \\ Jonathan Galant Dewandaru', \\ Muh. Ilham², Romly Arsyad ${ }^{3}$ \\ 1) Institut Pemerintahan Dalam Negeri \\ Program Magister Terapan Studi Pemerintahan Daerah Institut Pemerintahan Dalam Negeri \\ jonathangalant@ipdn.ac.id \\ ${ }^{2,3)}$ Institut Pemerintahan Dalam Negeri
}

\begin{abstract}
$T$ The focus of this research is to look the strategy of the Election Supervisory Agency in controlling civil servants involvement in general election in West Java Province, the factors that influence and determine the strategies used to implement supervision and control the civil servants involvement in general election in West Java Province. The research uses theory by George R. Terry related to the Supervision and Control and conduct a SWOT analysis and Litmus test to determine strategies. This research uses a qualitative method with a descriptive approach. In collecting data, researchers conducted observations, interviews and collected documents on the strategy of the Election Supervisory Agency in controlling civil servants involvement in general election in West Java Province.

The results showed that the implementation of supervision and controlling civil servants involvement in general election by Election Supervisory Agency had not run optimally. The existence of direct supervision and conrol but the availability of financial resources, facilities and infrastructure, and competent human resources are not fully owned and taken seriously. The influencing factors consist of internal factors and external factors which are then determined by the strategies that must be carried out to succeed based on SWOT analysis and Litmus test to get very strategic issues, including: Increasing government commitment in carrying out oversight and control of the civil servants involvement in general election, conduct coaching and prevention by conducting improvement to the civil servants, improve facilities and infrastructure to oversight and control the infraction of general election, improve the capacity of apparatus through training in supervision implementation of civil servants involvement in general election, Optimizing law enforcement towards the civil servants proven doing violation to the Code of Conduct regulated by the Law.
\end{abstract}

Keywords: strategy, supervision, control, civil servant, general election

\section{ABstrak}

$\mathrm{F}$ okus dari penelitian ini adalah melihat strategi Badan Pengawas Pemilu dalam Pengawasan Keterlibatan Aparatur Sipil Negara (ASN) pada pemilihan umum di Provinsi Jawa Barat, faktor-faktor yang memengaruhi serta menentukan strategi yang sebaiknya dilakukan untuk 
keberhasilan pelaksanaan pengawasan keterlibatan ASN dalam Pemilu di Provinsi Jawa Barat. Penelitian menggunakan teori oleh George R. Terry terkait pengawasan serta melakukan analisis SWOT dan Litmus test untuk menentukan strategi. Penelitian ini menggunakan metode kualitatif dengan pendekatan deskriptif. Dalam mengumpulkan data, peneliti melakukan observasi, wawancara dan mengumpulkan dokumen tentang strategi Badan Pengawas Pemilihan Umum (Bawaslu) dalam pengawasan keterlibatan Aparatur Sipil Negara (ASN) pada pemilihan umum di Provinsi Jawa Barat.

Hasil penelitian menunjukkan bahwa pelaksanaan pengawasan keterlibatan ASN dalam Pemilu oleh Bawaslu belum berjalan optimal. Adanya pengawasan dan pengendalian secara langsung, namun ketersediaan sumber daya finansial, sarana dan prasarana, dan sumber daya manusia yang kompeten belum sepenuhnya dimiliki dan diperhatikan dengan sungguhsungguh. Faktor-faktor yang memengaruhi terdiri dari faktor internal dan faktor eksternal yang kemudian ditentukan strategi yang sebaiknya dilakukan untuk keberhasilan berdasarkan analisis SWOT dan Litmus test didapatkan isu sangat strategis antara lain: Meningkatkan komitmen bersama pemerintah dalam melaksanakan pengawasan keterlibatan ASN pada pemilihan umum, Melakukan pembinaan dan pencegahan dengan melakukan pembinaan terhadap para ASN, Meningkatkan sarana dan prasarana pengawasan pelanggaran Pemilu, Membuat rencana kebutuhan dan percepatan pelaksanaan pengawasan pelanggaran Pemilu, Meningkatkan kapasitas aparatur melalui pelatihan pelaksanaan pengawasan keterlibatan ASN pada pemilihan umum, mengoptimalkan penegakan hukum terhadap ASN yang terbukti melakukan pelanggaran Kode etik yang diatur dalam Undang-Undang.

Kata kunci: strategi, pengawasan, aparatur sipil negara (ASN), pemilihan umum.

\section{PENDAHULUAN}

I ndonesia adalah salah satu negara yang menganut sistem pemerintahan demokrasi dengan memberlakukan Undang-Undang Dasar 1945 sebagai dasar negara dalam mewujudkan kedaulatan rakyatnya. Sebagai dasar negara, Undang-Undang Dasar 1945 telah mengatur tentang kedaulatan rakyat salah satunya dilaksanakan dengan proses Pemilihan Umum sebagai bentuk perwujudan sistem demokrasi di negara Indonesia yang tertuang pada Pasal 22 E ayat (1) sampai dengan (6) Perubahan Ke-3 Undang-Undang Dasar 1945 guna menjunjung hak-hak politik kewarganegaraan di Negara Kesatuan Republik Indonesia. Pemilihan umum adalah sarana demokrasi untuk membentuk sistem kekuasaan negara yang berkedaulatan rakyat dan permusyawaratan perwakilan yang digariskan oleh Undang-Undang Dasar 1945.
Berdasarkan Undang-Undang Dasar 1945 kekuasaan yang lahir melalui pemilihan umum adalah kekuasaan yang lahir dari bawah menurut kehendak rakyat dan dipergunakan sesuai dengan keinginan rakyat untuk sepenuhnya digunakan bagi kepentingan rakyat. Pemilihan umum merupakan salah satu proses untuk memperjuangkan kepentingan politik dalam bentuk seleksi serta pemilihan terhadap lahirnya wakil rakyat dan pemimpin dalam rangka perwujudan demokrasi, karena pemilihan umum merupakan suatu rangkaian kegiatan politik untuk menampung kepentingan rakyat, yang kemudian dirumuskan dalam berbagai bentuk kebijakan. Menurut Undang-Undang Dasar 1945 Pemilihan Umum adalah sarana kedaulatan rakyat yang dilaksanakan secara langsung, umum, bebas, rahasia, jujur dan adil. Pada Pasal 1 ayat (7) Undang-Undang No. 7 Tahun 2017 tentang Pemilihan Umum menyebutkan bahwa: "Penyelenggara Pemilu adalah lembaga yang menyelenggarakan Pemilu yang terdiri atas Komisi Pemilihan 
Umum, Badan Pengawas Pemilihan Umum, dan Dewan Kehormatan Penyelenggara Pemilihan Umum sebagai satu kesatuan fungsi Penyelenggaraan Pemilu untuk memilih anggota Dewan Perwakilan Rakyat, anggota Dewan Perwakilan Daerah, Presiden dan Wakil Presiden, dan untuk memilih anggota Dewan Perwakilan Rakyat serta untuk memilih Kepala Daerah secara langsung oleh rakyat".

Badan Pengawas Pemilu (Bawaslu) adalah sebagai salah satu lembaga penyelenggara Pemilu yang bertugas melakukan pengawasan terhadap penyelenggaraan Pemilu termasuk pemilihan umum kepala daerah (Pemilukada).

Tabel 1. Data laporan keterlibatan ASN pada Pemilu serta penyelesaian proses penjatuhan hukuman bagi ASN di Provinsi Jawa Barat 2015-2018

\begin{tabular}{|c|c|c|c|c|}
\hline NO & KABUPATEN/KOTA & $\begin{array}{c}\text { KASUS } \\
\text { KETERLIBATAN ASN } \\
(2015-2018)\end{array}$ & $\begin{array}{l}\text { PENJATUHAN } \\
\text { HUKUMAN }\end{array}$ & $\begin{array}{c}\text { BELUM } \\
\text { DIPROSES }\end{array}$ \\
\hline 1. & Kota Bandung & 55 & 11 & 44 \\
\hline 2. & Kota Tasikmalaya & 17 & 6 & 11 \\
\hline 3. & Kota Cimahi & 15 & - & 15 \\
\hline 4. & Kota Cirebon & 22 & - & 22 \\
\hline 5. & Kota Bekasi & 19 & 2 & 17 \\
\hline 6. & Kota Depok & 35 & - & 35 \\
\hline 7. & Kota Bogor & 43 & - & 43 \\
\hline 8. & Kota Sukabumi & 3 & - & 9 \\
\hline 9. & Kota Banjar & 9 & - & 9 \\
\hline 10. & Kabupaten Indramayu & 6 & 3 & 3 \\
\hline 11. & Kabupaten Kuningan & 4 & 1 & 3 \\
\hline 12. & Kabupaten Cirebon & 17 & 2 & 15 \\
\hline 13. & Kabupaten Majalengka & 8 & 1 & 7 \\
\hline 14. & Kabupaten Bandung Barat & 24 & 3 & 21 \\
\hline 15. & Kabupaten Garut & 19 & 5 & 14 \\
\hline 16. & Kabupaten Cianjur & 9 & 7 & 2 \\
\hline 17. & Kabupaten Tasikmalaya & 5 & - & 5 \\
\hline 18. & Kabupaten Subang & 12 & - & 12 \\
\hline 19. & Kabupaten Sumedang & 11 & 2 & 9 \\
\hline 20. & Kabupaten Pangandaran & 3 & 1 & 2 \\
\hline 21. & Kabupaten Karawang & 20 & 1 & 19 \\
\hline 22. & Kabupaten Purwakarta & 15 & - & 15 \\
\hline 23. & Kabupaten Bogor & 33 & - & 33 \\
\hline 24. & Kabupaten Ciamis & 6 & 3 & 3 \\
\hline 25. & Kabupaten Sukabumi & 1 & - & 1 \\
\hline 26. & Kabupaten Bandung & 27 & 4 & 23 \\
\hline 27. & Kabupaten Bekasi & 21 & 1 & 20 \\
\hline \multicolumn{2}{|c|}{ JUMLAH } & 463 KASUS & 54 KASUS & 412 KASUS \\
\hline
\end{tabular}

Sumber: Bawaslu Jawa Barat (2019) 
Bawaslu memiliki wewenang antara lain mengawasi pelaksanaan tahapan-tahapan Pemilu, menerima laporan-laporan dugaan pelanggaran Pemilu, dan menindaklanjuti temuan atau laporan kepada perseorangan/ lembaga/instansisebagaiterdugaatau pelaku pelanggaran Pemilu. Seiring berjalannya waktu, dengan adanya peraturan perundangundangan tentang penyelenggaraan Pemilu yang baru yaitu Undang-Undang No. 7 Tahun 2017 tentang Pemilihan Umum, maka ada penguatan kewenangan Badan Pengawas Pemilu (Bawaslu) dalam menjalankan tugas dan fungsinya sebagai lembaga pengawasan Pemilu.

Badan Pengawas Pemilu (Bawaslu) memiliki kewenangan memutus pelanggaran administrasi sehingga temuan pengawas Pemilu tidak hanya bersifat rekomendasi tetapi bersifat putusan yang harus dilaksanakan oleh para pihak baik penegak hukum ataupun para pelanggar dalam Pemilu. Badan Pengawas Pemilu (Bawaslu) juga diberikan mandat dasar berupa bertindak untuk pencegahan dan penindakan terhadap pelanggaran Pemilu dan sengketa Pemilu.

Penyelenggaraan Pemilihan umum melibatkan warga negara (rakyat) baik dalam hal pemungutan suara serta dalam hal pengambilan keputusan politik, baik langsung maupun tidak langsung yang merupakan salah satu ciri pemerintahan yang demokratis yang menjunjung ketentuan pemilihan umum. Aparatur Sipil Negara (ASN) merupakan warga Negara Indonesia yang memiliki hak politik, sehingga dapat berpartisipasi dalam penyelenggaraan pemilihan umum baik pemilihan umum Presiden dan Wakil Presiden maupun pemilihan umum Gubernur, Bupati/Wali kota serta para wakil rakyat. Keterlibatan Aparatur Sipil Negara (ASN) dalam kegiatan Pemilihan Umum setiap tahunnya semakin meningkat, berdasarkan Pasal 3 UndangUndang No. 7 Tahun 2017 tentang Pemilihan Umum menyebutkan bahwa Keterlibatan
Aparatur Sipil Negara (ASN) dalam Pemilihan Umum merupakan salah satu pelanggaran Pemilu.

Belum adanya penguatan hak Bawaslu dalam penegakan hukum kepada ASN secara langsung serta kurangnya sumber daya di lapangan menjadi masalah dalam mengoptimalkan berjalannya proses penyelenggaraan pemilihan umum yang langsung, umum, bebas, rahasia, jujur dan adil.

\section{Perumusan Masalah}

Dari identifikasi masalah tersebut di atas, maka rumusan masalah yang diteliti pada tesis ini adalah sebagai berikut.

1. Bagaimana pelaksanaan pengawasan Keterlibatan Aparatur Sipil Negara dalam Pemilu oleh Badan Pengawas Pemilu Provinsi Jawa Barat?

2. Apa saja faktor pendukung dan penghambat dalam pelaksanaan pengawasan keterlibatan Aparatur Sipil Negara (ASN) dalam pemilihan umum di Provinsi Jawa Barat?

3. Bagaimana Strategi yang tepat dalam pelaksanaan pengawasan Keterlihatan Aparatur Sipil Negara (ASN) dalam pemilihan umum oleh Badan Pengawas Pemilu Provinsi Jawa Barat?

\section{KAJIAN PUSTAKA}

\section{Konsep Strategi}

Rangkuti (2014: 6-7), strategi dapat dikelompokkan berdasarkan tiga tipe strategi, yaitu sebagai berikut.

\section{a. Strategi Manajemen}

Strategi manajemen meliputi strategi yang dapat dilakukan oleh manajemen dengan orientasi pengembangan strategi secara makro misalnya, strategi pengembangan produk, 
strategi penerapan harga, strategi pengembangan produk, strategi akuisisi, strategi pengembangan pasar, strategi mengenai keuangan dan sebagainya.

\section{b. Strategi Investasi}

Strategi investasi merupakan kegiatan yang berorientasi pada investasi, misalnya, apakah perusahaan ini melakukan strategi pertumbuhan yang agresif atau berusaha mengadakan penetrasi pasar, strategi bertahan, strategi pembangunan kembali suatu divisi baru atau strategi divestasi, dan sebagainya.

\section{c. Strategi Bisnis}

Strategi bisnis ini juga disebut strategi bisnis secara fungsional karena bisnis ini berorientasi kepada fungsi-fungsi kegiatan manajemen, misalnya strategi pemasaran, strategi produksi atau operasional, strategi distribusi, strategi organisasi, dan strategi-strategi yang berhubungan dengan keuangan.

Mengukur strategi menurut Musa Hubeis dan Mukhamad Najib (2008: 94-96) dapat dilakukan dengan menggunakan analisis SWOT (Strength, Weakness, Opportunities, Threats) di mana strength yaitu kekuatan, weakness yaitu kelemahan, opportunities yaitu peluang dan threats yaitu ancaman. Sejalan dengan ini, menurut Rangkuti (2014: 83) analisis SWOT dilakukan terhadap dua jenis lingkungan organisasi, yaitu lingkungan internal dan lingkungan eksternal. Dalam melakukan analisis eksternal, organisasi harus mengidentifikasi semua peluang (opportunities) yang berkembang menjadi tren pada saat itu, serta memperhatikan berbagai ancaman (threats) yang mungkin timbul dari lingkungan sekitar organisasi tersebut. Sedangkan analisis yang bersifat internal lebih memfokuskan pada berbagai kekuatan (Strengths) dan kelemahan (weakness) yang ada pada organisasi tersebut. Matriks SWOT dapat dilihat pada tabel 2 .

Berdasarkan matriks SWOT dapat disusun empat strategi utama yaitu:

1. Strategi SO, strategi ini dibuat berdasarkan jalan pikiran perusahaan, yaitu dengan memanfaatkan kekuatan yang dimiliki oleh perusahaan.

Tabel 2 Matriks Analisis SWOT

\begin{tabular}{|c|c|c|}
\hline Internal & $\begin{array}{l}\text { Strengths (S)/ } \\
\text { Tentukan 5-10 } \\
\text { faktor-faktor kekuatan } \\
\text { internal }\end{array}$ & $\begin{array}{l}\text { WEAKNESS }(\mathbf{W}) / \\
\text { Tentukan 5-10 } \\
\text { faktor-faktor kelemahan } \\
\text { internal }\end{array}$ \\
\hline OPPORTUNITIES (0) & Strategi SO & Strategi Wo \\
\hline $\begin{array}{l}\text { Tentukan 5-10 faktor- } \\
\text { faktor yang menjadi } \\
\text { peluang eksternal }\end{array}$ & $\begin{array}{l}\text { Ciptakan strategi yang } \\
\text { menggunakan kekuatan } \\
\text { untuk memanfaatkan } \\
\text { peluang }\end{array}$ & $\begin{array}{l}\text { Ciptakan strategi } \\
\text { yang meminimalkan } \\
\text { kelemahan untuk } \\
\text { memanfaatkan peluang }\end{array}$ \\
\hline ThreatS (T) & Strategi ST & Strategi WT \\
\hline $\begin{array}{l}\text { Tentukan 5-10 faktor- } \\
\text { faktor yang menjadi } \\
\text { ancaman eksternal }\end{array}$ & $\begin{array}{l}\text { Ciptakan strategi yang } \\
\text { menggunakan kekuatan } \\
\text { untuk mengatasi } \\
\text { ancaman }\end{array}$ & $\begin{array}{l}\text { Ciptakan strategi } \\
\text { yang meminimalkan } \\
\text { kelemahan dan } \\
\text { menghindari ancaman }\end{array}$ \\
\hline
\end{tabular}

Sumber: Rangkuti (2014: 83) 
2. Strategi ST, strategi ini menggunakan kekuatan yang dimiliki perusahaan untuk mengatasi ancaman.

3. Strategi WO, strategi ini diterapkan berdasarkan pemanfaatan peluang yang ada dengan cara meminimalkan kelemahan yang ada.

4. Strategi WT, strategi ini ditetapkan pada kegiatan yang bersifat defensif dan berusaha meminimalkan kelemahan yang ada dan menghindari ancaman.

Dengan demikian strategi merupakan suatu rencana untuk mencapai sasaran yang telah ditetapkan dengan mengacu pada kekuatan dan kelemahan dari organisasi dan dari peluang dan ancaman yang ada. Pendapat Rangkuti di atas merupakan pendapat peneliti yang digunakan dalam penelitian ini. Pendapat tersebut di atas sesuai dengan penentuan strategi yang diharapkan dapat menghasilkan keputusan terbaik dalam penyelesaian masalah dalam penelitian ini.

\section{Konsep Pengawasan}

Menurut G.R Terry (2008: 10), "Pengawasan adalah menentukan standar, mengukur pelaksanaan dengan tujuan-tujuan, menentukan sebab-sebab penyimpangan-penyimpangan dan mengambil tindakan-tindakan korelatif di mana perlu. Pengawasan dapat dirumuskan sebagai proses penentuan apa yang harus dicapai yaitu standar, apa yang sedang dilakukan yaitu pelaksanaan, menilai pelaksanaan dan bila perlu melakukan perbaikan-perbaikan sehingga pelaksanaan sesuai dengan rencana, selaras dengan standar (ukuran)".

Kemudian menurut G.R Terry (2008: 12), "Prinsip atau pengawasan ada empat yaitu:

1. Menentukan standar atau dasar bagi pengawasan

2. Mengukur pelaksanaan
3. Membandingkan pelaksanaan dengan standar

4. Memperbaiki penyimpangan dengan cara-cara tindakan yang tepat."

Adapun lima prinsip atau proses pengawasan menurut G.R. Terry (2008: 13) dapat dijelaskan sebagai berikut.

1. Tetapkan ukuran-ukuran atau standar pengawasan adalah ketentuan dasar yang menjadi ukuran dan pola untuk pelaksanaan pekerjaan atau produk yang dihasilkan. Standar harus jelas, logis, wajar, tidak muluk dan objektif.

2. Monitor hasil-hasil dan bandingkan dengan ukuran-ukuran adalah pengamatan pekerjaan yang berjalan dalam pelaksanaan kegiatan rencana yang dilakukan dengan membuat catatan sebagai laporan mengenai perkembangan proses manajemen.

3. Perbaiki penyimpangan-penyimpangan atau koreksi adalah langkah tindakan yang bertujuan untuk mencari kesalahan, juga memberikan bagaimana cara memperbaikinya dan menerangkan apa yang terjadi penyimpangan.

4. Ubah dan sesuaikan cara-cara pengawasan sehubungan dengan hasilhasil pengawasan dan perubahan kondisi-kondisi adalah bagaimana merubah atau menyesuaikan cara pengawasan yang dilakukan sesuai dengan keadaan seberapa jauh penyimpangan yang telah terjadi dari standar dan rencana serta sebab-sebab penyimpangan.

5. Berhubungan selalu selama proses pengawasan adalah adanya koordinasi dengan kontak langsung antarmanusia yang berkepentingan.

"Tujuan utama dari pengawasan ialah agar apa yang direncanakan menjadi kenyataan. Oleh karena itu agar sistem pengawasan benar-benar efektif artinya dapat merealisasikan tujuannya maka suatu 
sistem pengawasan setidak-tidaknya harus dapat dengan segera melaporkan adanya penyimpangan-penyimpangan dari rencana." (Manulang, 2006: 174).

Pada penelitian ini, peneliti menggunakan rujukan pendapat pengawasan oleh George R. Terry (2008: 10), "Pengawasan adalah mengukur pelaksanaan dengan tujuan-tujuan, menentukan sebabsebab penyimpangan-penyimpangan dan mengambil tindakan-tindakan korelatif di mana perlu. Pengawasan dapat dirumuskan sebagai proses penentuan apa yang harus dicapai yaitu standar, apa yang sedang dilakukan yaitu pelaksanaan, menilai pelaksanaan dan bila perlu melakukan perbaikan-perbaikan sehingga pelaksanaan sesuai dengan rencana, selaras dengan standar (ukuran)". Pernyataan George R. Terry selaras dengan tujuan peneliti mengamati pelaksanaan pengawasan keterlibatan aparatur sipil negara dalam Pemilu di Provinsi Jawa Barat.

\section{Konsep Demokrasi}

Konsep demokrasi sudah berkembang sejak 200 tahun yang lalu. Konsep ini telah diperkenalkan oleh Plato dan Aristosteles dengan isyarat untuk penuh hati-hati pada saat hendak menggunakan konsep demokrasi ini. Demokrasi itu memiliki dua sisi yang sangat berbeda, Di satu sisi sangat baik, namun di sisi lain juga dapat menjadi sangat kejam. Mungkin Indonesia menjadi salah satu penganut sistem demokrasi yang telah merasakan secara nyata apa yang di khawatirkan oleh Plato dan Aristosteles. Konsep demokrasi sangat mendewakan kebebasan, sehingga pada akhirnya nanti tidak mustahil dapat menimbulkan anarki. Oleh sebab itu, yang diperlukan di sini adalah bagaimana mekanisme yang paling tepat untuk mengontrol konsep demokrasi yang ada pada saat ini. Dalam penerapannya, konsep demokrasi di Negara Kesatuan Republik Indonesia dapat dipandang sebagai sebuah mekanisme dan cita-cita untuk mewujudkan suatu kehidupan berkelompok yang sesuai dengan apa yang terdapat dalam UUD 1945 yang disebut kerakyatan. Dapat disimpulkan juga bahwa konsep demokrasi atau pemerintahan rakyat yang diterapkan di negara Indonesia itu berdasarkan pada tiga hal, yaitu:

1. Nilai-nilai falsafah Pancasila atau pemerintahan dari, oleh, dan untuk rakyat berdasarkan sila-sila Pancasila;

2. Transformasi nilai-nilai Pancasila pada bentuk dan sistem pemerintahan;

3. Merupakan konsekuensi dan komitmen terhadap nilai-nilai Pancasila dan UUD 1945.

\section{Pemilihan Umum}

Menurut Ali Moertopo (2010: 56) Pemilu adalah sarana yang tersedia bagi rakyat untuk menjalankan kedaulatannya sesuai dengan azas yang termaktub dalam Pembukaan UUD 1945. Selanjutnya Suryo Untoro dalam Ramlan (2011: 101) menyebutkan Pemilu adalah suatu pemilihan yang dilakukan oleh warga negara Indonesia yang memiliki hak pilih untuk memilih wakil-wakilnya yang duduk dalam badan perwakilan rakyat. Tujuan dari Pemilu adalah sebagai perwujudan kedaulatan rakyat untuk menghasilkan pemerintahan negara yang berdasarkan Pancasila dan UUD 1945. Pemilihan umum merupakan salah satu ciri melekat ciri melekat pada Negara yang menganut sistem demokrasi.

UU No. 7 Tahun 2017 tentang Pemilihan Umum mengatur pada setiap tahapan dalam bentuk kewajiban, dan larangan dengan tambahan ancaman atau sanksi. Potensi pelaku pelanggaran Pemilu dalam UU Pemilu antara lain sebagai berikut.

1. Penyelenggara Pemilu yang meliputi anggota KPU, KPU Provinsi, KPU Kabupaten/Kota, anggota Bawaslu, Panwaslu Provinsi, Panwaslu Kabupaten Kota, Panwas Kecamatan, jajaran sekretariat dan petugas pelaksana lapangan lainnya; 
2. Peserta Pemilu yaitu pengurus partai politik, calon anggota DPD, DPR, DPRD, tim kampanye;

3. Pejabat tertentu seperti PNS, anggota TNI, anggota Polri, pengurus BUMN/ BUMD, Gubernur/pimpinan Bank Indonesia, Perangkat Desa, dan badan lain lain yang anggarannya bersumber dari keuangan negara;

4. Profesi media cetak/elektronik, pelaksanaan pengadaan barang dan distributor;

5. Pemantau dalam negeri maupun asing;

6. Masyarakat Pemilih, pelaksana survey/ hitungan cepat, dan umum yang disebut sebagai "setiap orang".

Pada dasarnya jika suatu negara ingin menyatakan diri sebagai negara demokrasi Pancasila melaksanakan pemilihan umum untuk melaksanakan kedaulatan rakyat dalam negara. Tetapi WNI yang belum memenuhi syarat untuk dipilih/memilih dalam Pemilu harus memperdalam pengetahuan tentang Pemilu dan bermoral Pancasila.

\section{Aparatur Sipil Negara (ASN)}

Aparatur Sipil Negara yang selanjutnya disingkat ASN adalah profesi bagi Pegawai Negeri Sipil dan pegawai pemerintah dengan perjanjian kerja yang bekerja pada instansi Pemerintah. Pegawai Aparatur Sipil Negara yang selanjutnya disebut Pegawai ASN adalah pegawai negeri sipil dan pegawai pemerintah dengan perjanjian kerja yang diangkat oleh pejabat pembina kepegawaian dan diserahi tugas dalam suatu jabatan pemerintahan atau diserahi tugas negara lainnya dan digaji berdasarkan peraturan perundang-undangan. Pegawai Negeri Sipil yang selanjutnya disingkat dengan PNS adalah warga negara Indonesia yang memenuhi syarat tertentu, diangkat sebagai pegawai ASN secara tetap oleh pejabat pembina kepegawaian untuk menduduki jabatan pemerintahan. Pegawai Negeri Sipil menurut Kamus Umum Bahasa Indonesia, "Pegawai" berarti "orang yang bekerja pada pemerintah (perusahaan dan sebagainya) sedangkan "Negeri" berarti negara atau pemerintah. Jadi Pegawai Negeri Sipil adalah orang yang bekerja pada pemerintah atau negara. Pengaturan profesi dan kerja ASN diatur dalam Undang-Undang No. 5 Tahun 2014 tentang ASN sebagai,mana diatur dalam peraturan perundang-undangan maka seorang ASN memiliki Asas, Prinsip, Nilai Dasar, serta Kode Etik dan Kode Perilaku yang wajib untuk dilaksanakan.

\section{METODE PENELITIAN}

Pada penelitian ini penulis menggunakan jenis penelitian yang bersifat kualitatif, dengan menggunakan metode penelitian kualitatif menurut Sugiyono (2017: 9) yang mendefenisikan, "metode penelitian kualitatif adalah metode penelitian yang berlandaskan pada filsafat postpositivisme atau enterpretif, digunakan untuk meneliti padakondisi objekyangalamiah". Selanjutnya Effendy (2010: 117) berpendapat bahwa, "Penelitian kualitatif adalah penelitian yang menjelaskan dan menganalisis perilaku manusia secara individual dan kelompok, prinsip atau kepercayaan, pemahaman atau pemikiran dan persepsi atau tanggapan".

Metode penelitian memiliki beberapa hal yang menjadikan metode penelitian tersebut berbeda dari metode lainnya. Perbedaan karakteristik ini sangat berpengaruh pada bagaimana penelitian tersebut dilakukan. Adapun karakteristik penelitian kualitatif menurut Moleong dalam Arikunto (2005: 4) yang harus dipenuhi, yaitu:

a. Latar ilmiah;

b. Manusia sebagai alat;

c. Metode kualitatif;

d. Analisis data secara induktif;

e. Teori dari dasar (grounded theory);

f. Deskriptif;

g. Lebih mementingkan proses daripada hasil; 
h. Adanya batas yang ditentukan oleh fokus;

i. Adanya kriteria khusus untuk keabsahan data;

j. Desain yang bersifat sementara;dan

k. Hasil penelitian dirundingkan dan disepakati bersama.

Lebih lanjut menurut Merriam, sebagaimana yang dikutip oleh Creswell dalam Patilima (2016: 60) "Ada enam asumsi dalam pendekatan kualitatif yang diperhatikan oleh peneliti yaitu:

1. Peneliti kualitatif lebih menekankan perhatian pada proses bukan pada hasil atau prosedur;

2. Peneliti kualitatif tertarik pada makna bagaimana orang membuat hidup, pengalaman dan struktur kehidupannya masuk akal;

3. Peneliti kualitatif merupakan instrumen pokok dalam pengumpulan dan analisis data. Data didekati melalui instrumen manusia bukan melalui inventaris daftar pernyataan atau alat lain;

4. Peneliti kualitatif melibatkan kerja lapangan. Peneliti secara fisik berhubungan dengan orang, latar belakang, lokasi atau institusi untuk mengamati atau mencatat Perilaku dalam latar alamiahnya;

5. Peneliti kualitatif bersifat deskriptif dalam arti peneliti tertarik proses, makna dan pemahaman yang dapat melalui kata atau gambar;dan

6. Proses penelitian kualitatif bersifat induktif. Peneliti membangun Abstrak, konsep, proposisi dan teori."

Pendapat ahli di atas menggambarkan bahwa ada hubungan antara metode kualitatif dan metode deskriptif, sebagaimana dijelaskan oleh Nazir (2014: 43) bahwa, "Penelitian deskriptif adalah suatu metode dalam meneliti status kelompok manusia, suatu objek, suatu set kondisi, suatu sistem pemikiran ataupun suatu kelas peristiwa pada masa sekarang". Sedangkan Nawawi (2003: 63) mengatakan bahwa, "Metode deskriptif tidak lebih daripada penelitian yang bersifat menemukan fakta seadanya (fact finding). Metode deskriptif merupakan langkah-langkah yang melakukan representasi objektif tentang gejala-gejala yang terdapat dalam masalah yang diselidiki".

Desain penelitian merupakan hal yang mutlak diperlukan dalam suatu penelitian. Penentuan desain penelitian yang telah digunakan dalam penelitian akan menentukan akurasi data hasil penelitian. Dengan kata lain, desain penelitian dimaksudkan agar sasaran atau target penelitian yang telah dicapai dapat dipertanggungjawabkan kebenarannya.

Berdasarkan berbagai penjelasan di atas, peneliti menyimpulkan bahwa metode penelitian deskriptif dengan pendekatan kualitatif adalah metode penelitian yang menjajaki atau menggali sesuatu hal/masalah secara mendalam dan komprehensif dari kumpulan informasi dengan membaca kejadian atau fenomena di sekitarnya untuk membantu menjelaskan dan menggambarkan permasalahan yang diteliti dengan mengutamakan analisis data secara induktif di mana akan ditarik simpulan secara proposisi atau teori guna menguatkan argumen. Cholid Narbuko (2010: 19) menambahkan bahwa:

"logika induktif adalah logika yang mempelajari arah penalaran yang benar dari sejumlah hal khusus sampai pada suatu simpulan umum yang bersifat kemungkinan, simpulan yang bersifat kemungkinan ini diperoleh dengan penalaran yang didasarkan pada pengamanan terhadap sejumlah kecil masalah sampai pada suatu simpulan diharapkan berlaku secara umum"

Sejalan dengan hal tersebut, maka penelitian ini merupakan penelitian deskriptif dengan pendekatan kualitatif untuk mendalami dan memahami serta 
menjelaskan Strategi Badan Pengawas Pemilu Dalam Pengawasan Keterlibatan Aparatur Sipil Negara Pada Pemilihan Umum Di Provinsi Jawa Barat.

\section{HASIL PENELITIAN DAN PEMBAHASAN}

\section{Badan Pengawasan Pemilihan Umum Provinsi Jawa Barat}

Bawaslu Provinsi Jawa Barat ditetapkan pada 21 Juni 2013 melalui Keputusan Ketua Bawaslu No. 540-Kep Tahun 2013 tentang Penetapan Anggota Badan Pengawas Pemilihan Umum Provinsi Jawa Barat sesuai dengan Undang-Undang No. 15 Tahun 2011 Pasal 72 ayat 4 dan 6 bahwa Ketua Bawaslu Provinsi dipilih oleh anggota Bawaslu Provinsi. Melalui keputusan tersebut maka terpilihlah Ketua Bawaslu serta pembagian masing-masing divisi serta kesekretariatan Bawaslu Provinsi Jawa Barat.

Dalam menciptakan Pemilihan Umum yang Langsung, Umum, Bebas, Rahasia, Jujur dan Adil maka Bawaslu Jawa Barat memiliki visi dan misi sebagai berikut.

Visi:

"Terwujudnya Bawaslu sebagai Lembaga Pengawal Terpercaya dalam Penyelenggaraan Pemilu Demokratis, Bermartabat, dan Berkualitas."

Misi:

1. Membangun aparatur dan kelembagaan pengawas Pemilu yang kuat, mandiri dan solid;

2. Mengembangkan pola dan metode pengawasan yang efektif dan efisien;

3. Memperkuat sistem kontrol nasional dalam satu manajemen pengawasan yang terstruktur, sistematis, dan integratif berbasis teknologi;

4. Meningkatkan keterlibatan masyarakat dan peserta Pemilu, serta meningkatkan sinergi kelembagaan dalam pengawasan Pemilu partisipatif;
5. Meningkatkan kepercayaan publik atas kualitas kinerja pengawasan berupa pencegahan dan penindakan, serta penyelesaian sengketa secara cepat, akurat dan transparan;

6. Membangun Bawaslu sebagai pusat pembelajaran pengawasan Pemilu baik bagi pihak dari dalam negeri maupun pihak dari luar negeri.

Keberhasilan lembaga pengawas Pemilu akan sangat berpengaruh dalam penetapan hasil Pemilu untuk itu sangat diperlukan kolaborasi yang baik oleh lembaga pelaksana pemilihan umum dalam menciptakan pemilihan umum sesuai yang diamanatkan dalam undang-undang yang berlaku dan telah ditetapkan.

\section{Pelaksanaan Pengawasan ASN dalam Pemilu oleh Badan Pengawas Pemilihan Umum Provinsi Jawa Barat}

Pada penelitian yang telah dilakukan sebelumnya telah menunjukkan bahwa kendala atau permasalahan besar dalam pelaksanaan Pengawasan keterlibatan ASN dalam Pemilu adalah proses birokrasi pelaporan serta penindakan yang tidak terarah dan kurangnya sumber daya manusia. Sehingga dibutuhkan kerja keras Bawaslu dalam mengawal proses penegakan hukum atau sanksi bagi ASN yang terbukti terlibat dalam Pemilu, Dengan demikian penelitian ini akan menganalisis pelaksanaan pengawasan keterlibatan ASN dalam Pemilu dan menentukan strategi yang tepat dalam pelaksanaan pengawasan keterlibatan ASN dalam Pemilu untuk mencapai tujuan terciptanya Pemilu yang Langsung, Umum, Bebas, Rahasia, Jujur dan Adil (Luberjurdil).

Konsep yang akan digunakan untuk menganalisis bagaimana Badan Pengawas Pemilu Provinsi Jawa Barat dalam melaksanakan tugas pengawasan tersebut adalah konsep pengawasan George R. Terry (2008), di mana pada konsep pengawasan tersebut ada empat hal yang dianalisis 
yaitu: (1) Penetapan Standar; (2) Penentuan Pengukuran; (3) Perbandingan Standar dan Pelaksanaan; dan (4) Melakukan Tindakan Koreksi. Kemudian untuk menentukan Strategi yang tepat penulis menggunakan konsep dari Rangkuti (2006) serta analisis SWOT (Strength, Weakness, Opportunities, dan Threat) yang dikemukakan oleh Bryson (2004).

\section{- Penetapan Standar}

Menurut Peraturan Bawaslu RI No. 102 Tahun 2000 tentang Standarisasi Nasional menjelaskan bahwa "Standar adalah spesifikasi teknis atau sesuatu yang dibakukan termasuk tata cara dan metode yang disusun berdasarkan konsensus semua pihak yang terkait dengan memperhatikan syarat-syarat keselamatan, keamanan, kesehatan, lingkungan hidup, perkembangan ilmu pengetahuan dan teknologi, serta pengalaman, perkembangan masa kini dan masa yang akan datang untuk memperoleh manfaat yang sebesar-besarnya". Setiap organisasi baik profit orientation maupun nonprofit orientation dalam mencapai tujuan kegiatan organisasinya selalu membutuhkan penetapan standar, pada Bawaslu berdasarkan Undang-Undang No. 7 Tahun 2017 tentang Pemilu menetapkan standar pelaksanaan pengawasan pelanggaran Pemilu yaitu: sarana dan pra sarana, sumber daya manusia dan sebagainya untuk kemudian diubah menjadi hasil organisasi.

\section{- Penentuan Pengukuran}

Menurut T. Hani Handoko (2008: 365) menjelaskan bahwa "Pengukuran pelaksanaan kegiatan adalah tahapan yang dilakukan setelah ditetapkannya standar pelaksanaan yang dilakukan proses berulang-ulang dan terus- menerus". Proses pengukuran pelaksanaan dapat dikatakan untuk dapat melihat sejauh mana pelaksanaan dijalankan sesuai dengan standar yang telah ditetapkan. Pelaksanaan pengawasan diharapkan dapat menghindari kemungkinan penyimpangan dan kesalahan dalam prosedur tentang apa yang telah direncanakan dapat berjalan secara efektif dan efisien. Berkaitan dengan Pengawasan Keterlibatan ASN dalam Pemilu di Provinsi Jawa Barat dengan memperhatikan sejauh mana para Sumber Daya yang berkompeten turut andil dalam pelaksanaan kegiatan terlebih dahulu sebelum menganalisis sejauh mana pelaksanaan dilakukan. Penentuan pengukuran pada penelitian ini meliputi, Bentuk Pelaksanaan dan Sumber Daya Kompeten.

\section{- Perbandingan Standar dan Pelaksanaan}

Setelah standar ditetapkan dan pengawasan dilakukan kemudian dengan melihat perbandingan apakah sesuai atau tidak dengan standar yang telah dibuat dengan fakta yang terjadi di lapangan maka dapatdilakukan perbandingan antara standar dan pelaksanaan pengawasan keterlibatan ASN dalam Pemilu. Perbandingan adalah membandingkan dua nilai atau lebih dari suatu besaran yang sejenis dan dinyatakan dalam cara yang sederhana (Ronald Chilcote, 2003: 30). Perbandingan merupakan salah satu bentuk pengendalian Badan Pengawas Pemilu dalam meningkatkan mutu dalam lingkungan tugasnya agar tujuan organisasi dapat tercapai secara efektif dan efisien. Untuk itu perbandingan dalam melaksanakan pengawasan keterlibatan ASN oleh Badan Pengawas Pemilu Provinsi Jawa Barat merujuk pada sejauh mana pelaksanaan pengawasan dengan standar yang telah ditetapkan.

\section{- Tindakan Koreksi}

Koreksi merupakan tahap akhir dari program pengawasan, melalui koreksi dapat diketahui bagaimana proses pengawasan dilaksanakan dan bagaimana kondisi kemajuan standar yang telah ditetapkan. Jika pengawasan dilakukan tanpa adanya koreksi dari pihak petugas pengawasan 
akan sia-sia dan terulangnya kesalahan yang sebelumnya. Secara umum koreksi bertujuan untuk memberikan gambaran tentang mutu pengawasan setelah disupervisi. Ormston dan Shaw (1994: 106) menyatakan bahwa, "Tujuan dari koreksi adalah untuk mengomunikasikan dengan jelas kepada audiens yang tidak profesional tentang kekuatan dan kelemahan, kualitas keseluruhan, standar, dan apa yang harus dilakukan jika peningkatan diperlukan".

\section{Faktor-Faktor yang Memengaruhi Pelaksanaan Pengawasan Keterlibatan ASN oleh Badan Pengawasan Pemilu Provinsi Jawa Barat}

Faktor-faktor yang memengaruhi dapat dilihat dari faktor internal dan faktor eksternal. Faktor-faktor tersebut dapat muncul dari dalam organisasi dan luar organisasi. Faktor internal yang memengaruhi pelaksanaan Pengawasan Keterlibatan ASN dalam Pemilu oleh Bawaslu Provinsi Jawa Barat dapat dilihat pada kekuatan (Strengths) dan kelemahan (weakness) sedangkan Faktor eksternal pelaksanaan Pengawasan Keterlibatan ASN dalam Pemilu oleh Bawaslu Provinsi Jawa Barat dapat dilihat pada peluang (opportunities) dan berupa ancaman (threats).

\section{Strategi yang Sebaiknya Digunakan untuk Keberhasilan Pelaksanaan Pengawasan Keterlibatan ASN dalam Pemilu oleh Bawaslu Provinsi Jawa Barat}

Teknik yang digunakan peneliti dalam menganalisis dan menyusun strategi dalam pembahasan sub bab ini adalah dengan menggunakan teknis analisis SWOT. Analisis SWOT digunakan sebagai alat untuk menganalisis permasalahan yang terdapat dalam rumusan masalah yang berhubungan dengan faktor-faktor yang memengaruhi yaitu faktor internal dan faktor eksternal dalam menyusun strategi yang digunakan untuk keberhasilan pelaksanaan Pengawasan Keterlibatan ASN dalam Pemilu oleh Bawaslu Provinsi Jawa Barat, yang kemudian peneliti tentukan isu-isu strategis menggunakan Litmus test. Analisis SWOT dapat diterapkan dengan cara menganalisis dan memilih berbagai hal yang memengaruhi variabel yakni kekuatan (Strengths), kelemahan (weakness), peluang (opportunities) dan ancaman (threats) yang kemudian diterapkan dalam matriks SWOT. Matriks SWOT ini dapat disusun empat strategi utama, yaitu strategi SO, strategi WO, strategi ST dan strategi WT. Berdasarkan identifikasi faktor-faktor internal dan eksternal, maka dapat diketahui 10 (sepuluh) isu strategis yang dapat digunakan untuk keberhasilan pelaksanaan Pengawasan Keterlibatan ASN dalam Pemilu oleh Bawaslu Provinsi Jawa Barat. Strategi tersebut antara lain sebagai berikut.

1. Meningkatkan komitmen Bawaslu dalam melaksanakan Pengawasan Keterlibatan ASN dalam Pemilu.

2. Mengoptimalkan fungsi pegawai yang ada untuk melaksanakan tugas masingmasing pada Pengawasan Keterlibatan ASN dalam Pemilu.

3. Melakukan pembinaan dan pengawasan secara rutin terhadap ASN.

4. Meningkatkan sarana dan prasarana Pengawasan Keterlibatan ASN dalam Pemilu.

5. Membuat rencana kebutuhan dan percepatan pelaksanaan Pengawasan Keterlibatan ASN dalam Pemilu.

6. Meningkatkan kapasitas aparatur melalui pelatihan pelaksanaan Pengawasan Keterlibatan ASN dalam Pemilu.

7. Mengintegrasikan program dengan meningkatkan peran serta Bawaslu daerah dan masyarakat.

8. Memaksimalkan Sentra Penegakan Hukum Terpadu (Gakkumdu) dalam 
pelaksanaan Pengawasan Keterlibatan ASN dalam Pemilu.

9. Mengoptimalkan penegakan hukum terhadap ASN yang terbukti terlibat dalam Pemilu.

10. Melaksanakan forum komunikasi dan koordinasi dengan perangkat daerah, ASN, serta masyarakat dalam pelaksanaan Pengawasan Keterlibatan ASN dalam Pemilu.

Berdasarkan hasil akumulasi perhitungan dengan menggunakan uji Litmus seperti tabel di atas, maka dapat diketahui strategi yang dapat digunakan untuk keberhasilan pelaksanaan Pengawasan Keterlibatan ASN dalam Pemilu oleh Bawaslu Provinsi Jawa Barat sebagai berikut.

1. Isu sangat strategis, meliputi:

a. Meningkatkan komitmen Bawaslu dalam melaksanakan Pengawasan Keterlibatan ASN dalam Pemilu.

b. Melakukan pembinaan dan pengawasan secara rutin terhadap ASN.

c. Meningkatkan sarana dan prasarana Pengawasan Keterlibatan ASN dalam Pemilu.

d. Membuat rencana kebutuhan dan percepatan pelaksanaan Pengawasan Keterlibatan ASN dalam Pemilu.

e. Meningkatkan kapasitas aparatur melalui pelatihan pelaksanaan Pengawasan Keterlibatan ASN dalam Pemilu.

2. Isu cukup strategis, meliputi:

a. Mengintegrasikan program dengan meningkatkan peran serta ASN dan masyarakat.

b. Memaksimalkan sentra penegak hukum terpadu dalam pelaksanaan Pengawasan Keterlibatan ASN dalam Pemilu. c. Melaksanakan forum komunikasi dan koordinasi dengan perangkat daerah, ASN, serta masyarakat dalam pelaksanaan Pengawasan Keterlibatan ASN dalam Pemilu

3. Isu bersifat operasional, meliputi:

a. Mengoptimalkan fungsi pegawai yang ada untuk melaksanakan tugas masing-masing pada Pengawasan Keterlibatan ASN dalam Pemilu.

b. Memaksimalkan saran dan prasarana dalam Pengawasan Keterlibatan ASN dalam Pemilu.

\section{SIMPULAN}

Berdasarkan hasil penelitian dan pembahasan, maka dapat peneliti simpulkan sebagai berikut.

1. Pelaksanaan pengawasan keterlibatan ASN dalam Pemilu oleh Badan Pengawas Pemilu (Bawaslu) Provinsi Jawa Barat, belum berjalan optimal. Salah satu indikator yang menyebabkannya adalah ketersediaan sumber daya yang cukup untuk melaksanakan pengawasan pelanggaran Pemilu yaitu sumber daya finansial, sarana dan prasarana pendukung dan sumber daya manusia yang berkompeten.

2. Faktor-faktor yang memengaruhi pelaksanaan Pengawasan oleh Bawaslu Provinsi Jawa Barat adalah sebagai berikut.

\section{Faktor Internal:}

a. Adanya Undang-Undang No. 7 Tahun 2017 tentang Pemilihan Umum sebagai pedoman pelaksanaan pengawasan pelanggaran Pemilu.

b. Adanya komitmen Badan Pengawas Pemilu (Bawaslu) Provinsi Jawa Barat dalam pelaksanaan pengawasan keterlibatan ASN dalam Pemilu.

c. Tegasnya Sentra Penegak Hukum Terpadu (Gakkumdu) sebagai 
sarana tepat untuk melaksanakan pengawasan dan penindakan pelanggaran Pemilu.

d. Adanya loyalitas pegawai Badan Pengawas Pemilu (Bawaslu) Provinsi Jawa Barat dalam melaksanakan tugas pengawasan keterlibatan ASN dalam Pemilu.

e. Terbatasnya sarana dan prasarana Badan Pengawas Pemilu (Bawaslu) Provinsi Jawa Barat dalam pelaksanaan pengawasan keterlibatan ASN dalam Pemilu.

f. Anggaran yang masih minim dalam pelaksanaan pengawasan pelanggaran Pemilu.

g. Kompetensi sumber daya aparatur yang belum memadai dalam melakukan pengawasan pelanggaran Pemilu.

h. Rendahnya kesadaran ASN dalam mempertahankan Integritas dan Netralitasnya.

i. Rendahnya partisipasi masyarakat dalam memberikan informasi mengenai Keterlibatan ASN dalam Pemilu.

\section{Faktor Eksternal:}

a. Adanya dukungan dan kerja sama baik dari sektor pemerintahan maupun masyarakat yang sadar akan integritas pelaksanaan Pemilu.

b. Adanya pelatihan-pelatihan yang diadakan oleh Badan Pengawas Pemilu (Bawaslu) Republik Indonesia dalam hal pelaksanaan pengawasan pelanggaran Pemilu

c. Adanya program-program Badan Pengawas Pemilu (Bawaslu) untuk pelaksanaan pengawasan pelanggaran Pemilu.

d. Adanya pembinaan terhadap panitia pengawas Pemilu (panwaslu) oleh Badan Pengawas Pemilu (Bawaslu) di seluruh Provinsi Jawa Barat. e. Laju pertumbuhan penduduk Provinsi jawa Barat yang semakin meningkat

f. Kondisi geografis Provinsi Jawa Barat.

g. Dampak Kebutuhan Belanja dan Pendapatan Pegawai.

h. Dampak perbedaan pendapatan Pegawai di setiap Pemerintah Daerah baik Provinsi maupun Kabupaten/Kota.

3. Strategi yang sebaiknya digunakan untuk keberhasilan pelaksanaan pengawasan keterlibatan Aparatur Sipil Negara (ASN) oleh Badan Pengawas Pemilu (Bawaslu) Provinsi Jawa Barat adalah:

a. Meningkatkan komitmen pemerintah dalam melaksanakan pengawasan pelanggaran Pemilu.

b. Perlunya komitmen Sumber Daya Manusia (SDM) Baik pelaku Pemilu maupun Panitia Pengawas Pemilu (Panwaslu) untuk melaksanakan tugas dan tanggung jawab dengan sebaik-baiknya.

c. Mengembangkan hubungan antara tokoh masyarakat dalam mengawasi berjalannya proses Pemilu.

d. perlu adanya penguatan Badan Pengawas Pemilu (Bawaslu) sebagai lembaga yang mengambil keputusan terkait penjatuhan sanksi bagi Aparatur Sipil Negara (ASN) yang terbukti melakukan pelanggaran dalam Pemilu sesuai ketentuan dan peraturan perundang-undangan yang berlaku.

\section{SARAN}

Berdasarkan simpulan di atas, maka peneliti memberikan saran sebagai bahan evaluasi dan masukan terkait pelaksanaan pengawasan dan pengendalian muatan lebih oleh Dinas Perhubungan Provinsi sebagai berikut. 


\section{Saran Praktis}

1. Terkait Penanganan Keterlibatan Aparatur Sipil Negara (ASN), Badan Pengawas Pemilu (Bawaslu) Provinsi Jawa Barat diharapkan dapat lebih fokus kepada ketersediaan sumber daya yang ada yaitu sumber daya finansial, sumber daya infrastruktur (sarana dan prasarana) dan sumber daya manusia yang kompeten dalam hal pengawas pelanggaran Pemilu oleh Aparatur Sipil Negara (ASN).

2. Penguatan wewenang Badan Pengawas Pemilu (Bawaslu) sebagai lembaga yang mengambil keputusan terkait penjatuhan sanksi bagi Aparatur Sipil Negara (ASN) yang terbukti melakukan pelanggaran dalam Pemilu.

3. Badan Pengawas Pemilu (Bawaslu) Provinsi Jawa Barat sebaiknya dapat melakukan studi banding dengan Bawaslu provinsi lain yang telah sukses melaksanakan pengawasan keterlibatan ASN dalam Pemilu seperti yang terjadi di Provinsi Jawa Barat.

\section{Saran Teoretis}

1. Untuk peneliti selanjutnya yang menggunakan objek penelitian yang sama, diharapkan dapat menggunakan desain penelitian dan teknik analisis data yang berbeda agar lebih memperbanyak sumber-sumber dan referensi yang akurat terkait permasalahan yang diangkat.

2. Diharapkan juga bagi yang hendak melakukan penelitian tentang pelaksanaan pengawasan Keterlibatan Aparatur Sipil Negara (ASN) dapat melakukan kajian dari permasalahan dan sudut pandang yang berbeda atau menggunakan variabel penelitian yang berbeda, sehingga nantinya akan memperluas khasanah pengetahuan bagi peneliti dan pembaca.

\section{DAFTAR RUJUKAN}

Arikunto, Suharsimi. 2013. Prosedur-Prosedur Penelitian. Jakarta: Rineka Cipta.

Arni, Muhammad. 2004. Komunikasi Organisasi. Jakarta: Bumi Aksara.

Assauri, Sofjan. 2016. Manajemen Operasi Produksi (Pencapaian Sasaran Organisasi Berkesinambungan) Edisi 3. Jakarta: PT Raja Grafindo Persada

Atmosudirjo, Prayudi. 1981. Hukum Administrasi Negara. Jakarta: Ghalia Indonesia.

Bongdan, Robert dan Taylor. 1992. Pengantar Metode Penelitian Kualitatif. Surabaya: Usaha Nasional.

Bungin, Burhan. 2011. Penelitian Kualitatif. Jakarta: Kencana Predana Media Group.

Creswell, W. Jhon. 2016. Research Design Pendekatan Kualitatif, Kuantitatif dan Mixed. Yogyakarta: Pustaka Pelajar.

Effendi, Usman. 2014. Asas Manajemen, cetakan ke II. Jakarta: Rajawali Press.

Effendy, Khasan. 2010. Memadukan Metode Kualitatif dan Kuantitatif. Bandung: CV Indra Prahasta.

Hungger, J. David and Wheleen, Thomas. 2009. Manajemen Strategis. Yogyakarta: Andi.

Lexy, J. Moleong. 2005. Metodologi Penelitian Kualitatif. Bandung: Remaja Rosdakarya.

Miles, M.B dan Huberman, A.M. 1984. Analisis Data Kualitatif (Terjemahan Tjetjep Rohendi Rohidi). Jakarta: UI.

Nawawi, Hadari. 2003. Metode Penelitian Sosial. Yogyakarta: UGM Press.

Nazir, Moh, 1988, Metode Penelitian, Jakarta, Ghalia Indonesia.

Ndraha, Taliziduhu. 2003. Kybernologi, (Ilmu Pemerintahan Baru) 1. Jakarta: Raneka Jaya.

Ndraha, Taliziduhu. 2003. Kybernologi, (Ilmu Pemerintahan Baru) 2. Jakarta: Raneka Jaya.

Ndraha, Taliziduhu. 2005. Kybernologi, (Ilmu Pemerintahan Baru) 3. Jakarta: Raneka Jaya.

Ndraha, Taliziduhu. 2005. Kybernologi, (Ilmu Pemerintahan Baru) 4. Jakarta : Rineka Cipta 
Purwanto, Irwan. 2008. Manajemen Strategic. Bandung: CV Irama Widya.

Rangkuti, Freddy. 2016. Teknik Membedah Kasus Bisnis Analisis SWOT. Jakarta: Gramedia.

Rasyid. 2000. Makna Pemerintahan. Jakarta: PT Mutiara Sumber Widya.

Robbins, Stephen. 2013. Organizational Behavior. New Jersey: Pearson Education.

Siagian, P. Sondang. 2006. Organisasi Kepemimpinan dan Perilaku Administrasi. Jakarta: Gunung Agung.

Staphanie, K. Marrus. 2002. Desain Penelitian Manajemen Stratejik. Jakarta: Rajawali Press

Sugiyono. 2013. Metode Penelitian Pendidikan Pendekatan Kuantitatif, Kualitatif dan $R \& D$. Bandung: Alfabeta.

Suradinata, Ermaya. 1998. Manajemen Pemerintahan dan Otonomi Daerah. Bandung: Ramadan.

Syafiie, Kencana Inu. 2011. Pengantar Ilmu Pemerintahan. Bandung: Refika Aditama.

Yunus, Eddy. 2016. Manajemen Strategis. Yogyakarta: Andi.

\section{Peraturan Perundang-Undangan}

Undang-Undang Dasar Negara Republik Indonesia Tahun 1945

Peraturan Presiden Republik Indonesia No. 68 Tahun 2018 tentang Kedudukan, Fungsi, Wewenang, Organisasi dan Tata Kerja Sekretariat Jenderal, Badan Pengawas Pemilihan Umum, Sekretariat Badan Pengawas Pemilihan Umum Provinsi Dan Sekretariat Badan Pengawas Pemilihan Umum Kabupaten/Kota

Undang-Undang No. 7 Tahun 2017 tentang Pemilu

Undang-Undang No. 5 Tahun 2014 tentang Aparatur Sipil Negara

Undang-Undang No. 23 Tahun 2014 tentang Pemerintahan Daerah

Peraturan Pemerintah No. 53 Tahun 2010 tentang Displin PNS

Peraturan Pemerintah No. 11 Tahun 2017 tentang Manajemen pegawai Negeri Sipil
Keputusan Kepala Badan Pengawas Pemilu No. 69 Tahun 2014 tentang Tata Organisasi Sekretariat Badan Pengawas Pemilihan Umum Provinsi dan Tata Organisasi Sekretariat Badan Pengawas Pemilihan Umum Kabupaten/Kota

\section{Tesis dan Jurnal}

Handayani Rahma. 2018. Pelaksanaan Prinsip Netralitas Pegawai Negeri Sipil (PNS) Dalam Pemilihan Umum Kepala Daerah Di Kota Yogyakarta). Universitas Muhammadiyah Yogyakarta. Tesis: Magister Ilmu Hukum.

Aulia Fallah. 2013. Netralitas Pegawai Negeri Sipil (PNS) Dalam Pemilihan Umum Kepala Daerah (Pemilukada) Di Kabupaten Takalar. Universitas Gajah Mada. Tesis: Magister Ilmu Hukum

Sidik Ali. 2014. Peran Badan Pengawas Pemilihan Umum Dalam Penegakan Hukum Pemilihan Umum. Universitas Lampung. Tesis: Magister Ilmu Pemerintahan.

Firman. 2016. Meritokrasi Dan Netralitas Aparatur Sipil Negara (Asn) Dalam Pengaruh Pilkada Langsung. Jakarta: Jurnal Sosial Politik.

Sudrajat Tedi. 2010. Rekonstruksi Hukum Atas Pola Penanganan Pelanggaran Asas Netralitas Pegawai Negeri Sipil. Jakarta: Jurnal Sosial Politik.

\section{Internet}

https://id.wikipedia.org/wiki/Pemilihan_umum

https://makalah-update.blogspot.com/2012/12/ h u k u m - pelang gara n - P e m i lu-menurut-undang.html

https://www.scribd.com/doc/26138548/Download-Tesis-Gratis-1134(\&12

http://id.portalgaruda.org/?ref=browse \&$\bmod =$ viewjournal\&journal=6751/ meritokrasi_dan_netralitas_aparatur_ sipil_negara_(asn)_dalam_pengaruh_ Pilkada_langsung-001

https: / /www.researchgate.net/publication/322113328_Jurnal_Nasional-Pemilu-3397 